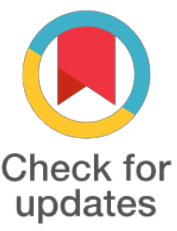

${ }^{*}$ For correspondence:

bnelson@bccrc.ca

Competing interests: The authors declare that no competing interests exist.

Received: 2017-04-30

Accepted: 2017-05-29

Published: 2017-09-05

Copyright The Author(s) 2017. This article is published with open access by BioMedPress (BMP).

This article is distributed under the terms of the Creative Commons Attribution License (CC-BY 4.0) which permits any use, distribution, and reproduction in any medium, provided the original author(s) and the source are credited.

\section{Customizing cancer immunotherapies to match the intrinsic tumor microenvironment}

\author{
Brad Nelson \\ Director and Distinguished Scientist, Deeley Research Centre, BCCA \\ Professor, Biochemistry and Microbiology, UVIC \\ Adjunct Professor, Biology, UVIC; Professor, Medical Genetics, UBC \\ Canada
}

\section{Abstract}

Tumor-infiltrating lymphocytes (TIL) are associated with survival in virtually every human cancer studied, but the mechanisms by which they confer protective immunity remain incompletely understood. Focusing on ovarian cancer, our group applies genomic and molecular pathology approaches to define the mechanisms by which the immune system responds to the evolving tumor genome over space and time. We have shown that optimal anti-tumor immunity involves interactions between $\mathrm{T}$ cells and antibody-producing B cells and plasma cells in the tumor microenvironment. Moreover, we have identified three patterns of TIL response in ovarian cancer, each carrying distinct implications for immunotherapy. We are translating these insights into clinical trials involving adoptive transfer of tumor-reactive $\mathrm{T}$ cells.

Keywords

Funding

References 